\title{
The Effect of the Competency of the Application, Regulatory Completeness and Implementation of the Siskeudes Application on Effectiveness Gampong Budget Management (Study in Gampong-Gampong in the District of Sigli City, Pidie Regency)
}

\author{
Ahmad Husnizal $^{1}$, Ridwan Ibrahim ${ }^{2}$, Syukriy Abdullah ${ }^{3}$ \\ ${ }^{1,2,3}$ Universitas Syiah Kuala, Banda Aceh, Indonesia
}

\begin{abstract}
The aim of this research is to examine the influence of state apparatus competency, completeness of regulations and the implementation of SISKEUDES application both as simultaneous and separately on the effectiveness of village fund management in sub-districs of Sigli city, district of Pidie. The research population were all villages in sub-district of Sigli city, District of Pidie, which were 15 villages in total, with research respondents including; Village headman, Village secretary, Treasurer, Head of General Affairs and Head of Development Affairs. The source of data used primary data which was questionnaires results of respondents. The data collection technique was conducted by the documentation. The analytical method was Multiple Linear Regression Analysis. The results showed that both simultaneous and separatedly, Competence apparatus, the completeness of regulations and the implementation of the SISKEUDES application together have a positive effect on the effectiveness of village budget management. Competence apparatus has a positive effect on the effectiveness of village budget management. Completeness of regulations has a positive effect on the effectiveness of village budget management. The application of the SISKEUDES application has a positive effect on the effectiveness of village budget management.
\end{abstract}

Keywords

state apparatus competency, regulations, SSKEDES; effectiveness fund, village

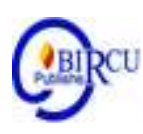

\section{Introduction}

The enactment of Law No.6 / 2014 concerning Villages brings a new paradigm in village development (Gampong is the name of a village for the Aceh region). Building Indonesia must start from the village as the foremost part of the development movement efforts that originate from community initiatives to achieve equitable prosperity for all Indonesian people. The Village Law also gives gampong authority to manage their own territory, including managing the village budget. Budget management starts from planning, implementation, administration, reporting to accountability. The gampong budget is compiled in the form of the Gampong Income and Expenditure Budget (APBG) document of Pemendagri No. 20/2018).

In Aceh Province, the gampong budget, especially those sourced from the central fund, increased on average from year to year. The gampong budget for Aceh Province in 2015 was around 1.7 trillion, in 2016 around 3.82 trillion, 2017 around 4.98 trillion, in 2018 around 4.45 trillion, and in 2019 around 4.54 trillion (aceh.tribunnews.com, 2019). In Pidie District, the gampong budget, especially those sourced from the central fund, has decreased from year to year on average. In 2017, the village budget for Pidie Regency was 
around 542 billion, in 2018 it was around 497 billion, in 2019 it was around 523 billion (spanint.kemenkeu.go.id, 2020). Large gampong budgets must be managed effectively so that the use of gampong budgets is in accordance with the Village Law.

The gampong government must prepare the gampong budget and the realization of the gampong budget according to the stipulated rules and time targets. This right is a condition so that the management of the gampong budget, whether sourced from the central government or regional government, can be implemented properly. The gampong budget must be prepared in the period from September to December of the previous year and a village budget realization report must be prepared as of December 31 of the current year.

Pidie Regency consists of 730 gampongs, which are currently still finding several problems related to village budget management. Among the problems are as many as 8 (eight) villages consisting of Gampong Teungoh Mangki, Gampong Asan, Gampong Dayah Baroh, Gampong Geunteng Timur, Gampong Rungkom, Gampong Neuheun, Gampong Dayah and Gampong Kupula until now they are still constrained by the distribution of village budgets, because of the village budget. have not submitted the Village Accountability Report (LPJ) for the previous fiscal year. A total of 2 (two) gampongs, consisting of Gampong Genteng Timur and Neuheun, are threatened with failing to disburse the gampong funds in 2019 because the gampong has not been able to complete the village budget documents for the current year until mid-2019 (Sinarpidie, 2019).

Several variables are thought to affect the effectiveness of budget management. These variables are; apparatus competence (Elfin, Wawo and Husin, 2019); completeness of regulations (Elfin, Wawo and Husin, 2019); and the SISKEUDES application (Herwan, 2019; Ridwan, 2019). The first factor is competence. In order to realize effective village financial management, village officials must have quality human resources, supported by an educational background, training and have experience in finance (Wardani and Andriyani, 2017). Lack of competence in understanding and applying accounting logic will have an impact on the quality of financial reports, and allow reports to be inconsistent with the standards set by the government (Ferina, Burhanuddin and Lubis, 2014).

The second factor is the completeness of regulations. Regulation is the legal basis for gampong budget management. Management of the gampong budget is part of regional and state financial management which has a legal basis. The management of the gampong budget is regulated by a set of regulations starting from the highest, namely Law Number 6 of 2014 concerning Villages to the lowest regulations, namely Regional Regulations and Regent / Mayor Regulations.

The third factor is the application of the SISKEUDES application. The government together with the Ministry of Home Affairs and the Financial and Development Supervisory Agency (BPKP) encourage accountability for village budget management through the SISKEUDES application. The SISKEUDES application developed by BPKP is currently computer-based so that village officials can more easily manage village development expenditures. The SISKEUDES application is a village finance application that is transparent and accountable to improve the quality of village budget governance.

Research related to the application of the SISKEUDES application. This study tries to fill in the gaps associated with these information technology variables. This research was conducted in gampongs in the District of Sigli City, Pidie Regency. The gampongs in this sub-district were chosen because of their location in the center of the district so that they become examples and benchmarks of budget management for gampongs in the surrounding sub-districts. 


\section{Review of Literatures}

\subsection{Agency Theory}

The people are the highest interest holders in a country as the giver of authority assumed to be the principal. The government, which is given the authority to carry out state management tasks in the interests of the people, is assumed to be the agent. The government can be in the form of the central government or regional government which is tasked with exercising the authority to manage state resources for the benefit of the community (Halim and Abdullah, 2006).

Modern democracies are based on a series of principal-agent relationships (Lane, 2000). The agency principal relationship framework is a very important approach to analyzing public policy commitments. Principal-agent theory analyzes the contractual arrangement between two or more individuals, groups, or organizations. One party (principal) enters into a contract, either implicitly or explicitly, with the other party (agent) in the hope that the agent will act / perform the job as desired by the principal. Principals can minimize agency conflicts by monitoring and supervising agents (Halim and Abdullah, 2006).

Agency in gampong budget management is shown in 3 (three) relationships. First, the relationship between the regional head as the principal and the village head as the agent. This is shown in Permendagri No.113 of 2014 article 2, in which the Village Head as the holder of village financial management power is obliged to submit a report to the Regent / Mayor through the Camat, in the form of the necessary reports regarding village budget management. Second, the relationship between the village head as the principal and the village apparatus as the agent. This is indicated in Permendagri No.113 of 2014 article 3 , where the village head in implementing village financial management is assisted by PTPKD, which consists of the Village Secretary, Section Head and Treasurer. Third, the relationship between the people as the principal and the village head as the agent. This is indicated in Permendagri No.113 of 2014 article 40 which states that the village budget and its responsibilities must be informed to the public in writing and with information media that is easily accessible to the public. The gampong government has the obligation to announce to the public the accountability for the use of APBDesa.

\subsection{Effectiveness of Gampong Budget Management}

Effectiveness is the relationship between output and goals, the greater the contribution (contribution) of output to the achievement of goals, the more effective the organization, program or activity is (Mahmudi, 2005). Effectiveness focuses on the outcome (result), program, or activity that is considered effective if the resulting output can meet the expected objectives. Village budget management refers to Permendagri No.113 of 2014 which states that regional financial management is the entire activity which includes planning, implementation, administration, reporting, and accountability. The management of the gampong budget is an effort to support the implementation of Village Government, the implementation of Village development, the development of Village communities and the empowerment of Village communities. 


\subsection{Apparatus Competence}

Competence is a characteristic of someone who has skills, knowledge, and abilities to carry out a job (Winidyaningrum and Rachmawati, 2010). Individual competence includes capacity, namely the ability of a person or individual, an organization (institution), or a system to carry out functions or authority to achieve its goals effectively and efficiently (Nurillah, 2014). Capacity must be seen as the ability to achieve performance, to produce outputs and outcomes.

Agency theory has a main principle in the form of a working relationship between two parties, namely the party who gives authority (principal) and the party who receives the authority (agent) in a form of cooperation. The central government, which represents the people as the principal, is assumed to be only interested in reports and expenditure items that are in accordance with the village fund proposal, while the village government tries to present reports and expenditure items in accordance with the wishes of the central government so that in the future they will receive funds again because reports and expenditure items meet the requirements. (Murthy and Jack, 2017).

Quality apparatus competence from the gampong government is needed so that budget management is in line with expectations. The gampong budget manager must have good competence so that the gampong budget can be managed effectively. In Pidie Regency Qanun Number 8 of 2011 Article 33 states that the requirements to become a village secretary / apparatus must have a minimum high school education, have knowledge of gampong governance and finance.

\subsection{Completeness of Regulations}

Regulationis a rule made to control a group, institution / organization, and society in order to achieve certain goals. The management of the gampong budget is regulated by a set of regulations starting from the highest, namely Law Number 6 of 2014 concerning Villages to the lowest regulations, namely Regional Regulations and Regent / Mayor Regulations. In the statutory system there is a hierarchy of statutory regulations.

Local governments have the responsibility of drafting regulations to support central government regulations, complete regulations really help the village government in managing the village budget (Elfin, Wawo and Husin (2019). Local governments must disseminate various village fund regulations to increase the capacity of the apparatus, especially in management gampong budget The gampong government as the agent will try to comply with regulations in accordance with the stipulations of the central government as principal so that in the future it will continue to receive funds from the central order as expected.

\subsection{Application of the SISKEUDES}

BPKP is mandated to oversee financial accountability and national development, including managing village budgets. The Village Financial System Application (SISKEUDES) issued by BPKP is an application used for village budget management. This application helps ensure a structured village / gampong budget management cycle starting from planning, implementation, administration, reporting, accountability and supervision. The use of the SISKEUDES application provides space for village government agencies to be more efficient, effective and facilitate the delivery of information, and facilitate community participation (Ridwan, 2019).

Explanation of Government Regulation No. 56 of 2005 states that local governments are obliged to develop and utilize information technology to increase the effectiveness of regional financial management and public services. The use of information technology 
allows local governments to work in an integrated manner by simplifying access between work units (Herwan, 2019). The local government as an agent is obliged to encourage the gampong government to use the SISKEUDES application in village budget management as the wish of the central government as the principal. Local governments also need to carry out socialization and training so that the capacity of the apparatus related to the SISKEUDES application is well understood.

The use of SISKEUDES provides space for village / gampong government agencies to be more efficient, effective and facilitate the delivery of information. This system makes it easier for the village government to prepare village programs and budgets. The information and communication system supports the village in implementing transparent, accountable and credible governance, and facilitates community participation (Ridwan, 2019).

\subsection{Hypothesis}

In accordance with the above framework, the hypothesis can be formulated as follows:

H1: Apparatus competence, completeness of regulations and application of the SISKEUDES application jointly influence the effectiveness of village budget management.

$\mathrm{H} 2$ : Apparatus competence affects the effectiveness of budget management gampong.

H3: Completeness of regulations affects the effectiveness of village budget management.

H4: The application of the SISKEUDES application affects the effectiveness of village budget management.

\section{Research Methods}

\subsection{Research Design, Sources and Data Collection Techniques}

This research was conducted to test the hypothesis. Research locations are in gampongs in the District of Sigli City, Pidie Regency. The population covers all gampongs totaling 15 (fifteen) gampongs with 5 (five) village rosponden persons, so that the total number of respondents is 75 (seventy five) people. Research respondents consisted of the Village Head (Keuchik), the village secretary (Sekdes), the Treasurer, the Head of General Affairs (Kaur) and the Head of Development Affairs (Kaur). The data used are primary data in the form of questionnaires that have been collected from respondents and secondary data in the form of regulations, books, articles and journals.

\subsection{Analysis Method}

This study uses multiple regression analysis to see the effect of the independent variable on the dependent variable. Data analysis uses SPSS (Statistical Package for Social Science) software, because this software has high accuracy of calculation results and the time needed to process data is relatively shorter. The multiple regression equation is as follows:

$$
\mathbf{Y}=\boldsymbol{\alpha}+\beta 1 \mathrm{X} 1+\beta 2 \mathrm{X} 2+\beta 3 \mathrm{X} 3+\varepsilon
$$

Note:

$\mathrm{Y}=$ Effectiveness of Budget Management

$\alpha=$ Constant

$\beta 1,2,3=$ Regression coefficient

$\mathrm{X} 1=$ Apparatus Competence

$\mathrm{X} 2$ = Completeness of Regulation

$\mathrm{X} 3=$ Implementation of the SISKEUDES application

$\varepsilon=$ error terms 


\section{Results and Discussion}

\subsection{Validity Test Results}

The validity test was conducted using the Pearson Product Moment coefficient of correlation. The critical value of $5 \%$ (for $\mathrm{N}=15$ ) is 0.514 . The test results show that the correlation coefficient obtained from each item of the variable is the effectiveness of village budget management(Y), competence (X1), completeness of regulations (X2),application of the SISKEUDES application (X3)all of them are above the critical value of the product moment correlation (correlation coefficient> 0.514) so that the questionnaire used can be declared valid.

\subsection{Reliability Test Results}

Reliability testing is done by calculating the value of Cronbach's alpha for each research variable. The test results show that each instrument in this study is reliable (reliable) because the Cronbach's Alpha value is greater than 0.6. The effectiveness of Gampong Budget Management (Y) is 0.944, Apparatus Competence (X1) is 0.937, Regulatory Completeness (X2) is 0.936 and the SISKEUDES Application Application (X3) is 0.983). It is concluded that the questionnaire used as a measuring tool in this study is reliable.

\subsection{Classical Assumption Test Results}

The classical assumption test is carried out to state the feasibility of the data processed for testing the hypothesis of this study. The results of the study concluded that the processed data were normally distributed. Multicollinearity was not found with a Variance Inflation Factor (VIF) of 4.961 for the apparatus competency variable, 7,108 for the regulatory completeness variable, and 5,326 for the variable use of the siskuedes application. There was no specific pattern found in the distribution of data so that the regression model did not occur heteroscedasticity.

\subsection{Hypothesis Testing Results}

Hypothesis testing is done to prove the hypothesis based on data obtained from the field using multiple linear regression models. The results of multiple linear regression tests are as in Table 1:

Table 1. The results of multiple linear regression tests

\begin{tabular}{|c|c|c|c|l|}
\hline No. & $\begin{array}{c}\text { Variable } \\
\text { Name }\end{array}$ & $\begin{array}{c}\text { Regression } \\
\text { Coefficient }(\beta)\end{array}$ & Info & Conclusion \\
\hline 1 & $\begin{array}{c}\text { Apparatus } \\
\text { Competence }\end{array}$ & 0.423 & $\begin{array}{c}\beta \neq \\
0\end{array}$ & Take effect \\
\hline 2 & Completeness \\
& 0.690 & $\begin{array}{c}\beta \neq \\
0\end{array}$ & Take effect \\
\hline 3 & Application & 0.282 & $\beta \neq$ & Take effect \\
& of the & & & \\
& SISKEUDES & & & \\
\hline 4 & application & & \\
\hline 5 & F value $=21,922 ;$ Sig. $\mathrm{F}=0,000$ \\
\hline
\end{tabular}


Based on table 1 it is obtainedThe multiple linear regression equation is as follows: $\mathrm{Y}=0,798+0,423 \times 1+0,690 \times 2+0,282 \times 3+\varepsilon$

Obtained a constant value of 0.798 means that the competence of the apparatus (X1), completeness of regulations (X2), andapplication of the SISKEUDES application (X3) considered constant, then the value effectiveness of village budget management is 0.798 on a five-point Likert scale.

\subsection{Concurrent Effect Testing}

The results of testing the effect together with multiple linear regression show the coefficient of determination (R2) the largest is 0.857 so that this regression equation can determine $85.7 \%$ of the independent variables needed to explain the phenomenon of change in variable $Y$, namely the Effectiveness of Budget Management. The determination of the hypothesis states if there is at least one $\beta \mathrm{i} \neq 0(\mathrm{i}=1,2,3)$ : Ha is not rejected, meaning that the competence of the apparatus, completeness of regulations and the application of the SISKEUDES application jointly influence the effectiveness of village budget management. Because this study uses the census method, to test the effect of the independent variables together on the dependent variable, a significance test is not carried out (Sugiyono, 2009: 65).

The joint effect can also be seen in the coefficient of determination (R2) which can be seen in Table 2:

Table 2. Result of the Coefficient of Determination (R2)

\begin{tabular}{|l|l|l|}
\hline No. & Information & Score \\
\hline 1 & R & 0.926 \\
\hline 2 & R Square (R2) & 0.857 \\
\hline 3 & Adjusted R Square & 0.818 \\
\hline
\end{tabular}

Based on Table 2, the Correlation Coefficient (R) value is 0.926 (close to the value 1), this value shows the strength of the relationship obtained by the variable apparatus competence, completeness of regulations and the application of the SISKEUDES application to the variable effectiveness of village budget management. Furthermore, the coefficient of determination (R2) is 0.857 or $85.7 \%$. This effect of $85.7 \%$ means that the competence of the apparatus, the completeness of regulations and the application of the SISKEUDES application jointly influence the effectiveness of village budget management by $85.7 \%$, and the remaining $14.3 \%$ is influenced by other variables that are not included. in this research model.

\subsection{Partial Influence Testing}

\section{a. Effect of Apparatus Competence on the Effectiveness of Gampong Budget Management}

The regression coefficient $(\beta 1)$ obtained is 0.423 , indicating that each increase in the competence of the apparatus by 1 unit of interval scale, there is a positive effect on the effectiveness of village budget management of 0.423 units of interval scale. The results of this study are in accordance with the research Sapartiningsih, Suharno and Kristianto (2018) who state that the better the quality of human resource competence, the better the accountability for managing village funds. In addition, the research results of Elfin, Wawo and Husin (2019)indicates that kompetency of village officials has a positive and significant effect on village financial management. 


\section{b. Effect of Completeness of Regulations on the Effectiveness of Gampong Budget Management}

The regression coefficient $(\beta 2)$ obtained is 0.690 , indicating that every increase in the completeness of the regulation by 1 unit of interval scale, there is a positive effect on the effectiveness of village budget management of 0.690 units of interval scale. The results of this study are in accordance with the results of research conducted by Elfin, Wawo and Husin (2019) showing that the availability of regulations is able to contribute significantly in realizing better village financial management. In addition, the results of Indrajaya's (2017) study show that comprehensive regulations from the central and regional levels assist village officials in carrying out their duties as village budget managers.

\section{c. The Effect of Siskeudes Application on the Effectiveness of Gampong Budget Management}

The regression coefficient ( $\beta 3$ ) obtained is 0.282 , indicating that every increase in the application of the SISKEUDES application of 1 interval scale unit has a positive effect on the effectiveness of village budget management of 0.282 units of interval scale. The results of this study are in accordance with the research conducted by Ridwan (2019), that the use of the SISKEUDES application will improve better village financial management. Similar results were expressed by Irvan, Mus, Su'un, \& Sufri (2017) which proved that the implementation of the SISKEUDES application had an effect on village financial management.

\section{Conclusion}

The conclusions of this study are: Competence apparatus, the completeness of regulations and the implementation of the SISKEUDES application together have a positive effect on the effectiveness of village budget management. Competence apparatus has a positive effect on the effectiveness of village budget management. Completeness of regulations has a positive effect on the effectiveness of village budget management. The application of the SISKEUDES application has a positive effect on the effectiveness of village budget management.

The limitations of this study are: This study uses three independent variables, there are many other variables that affect the effectiveness of village budget management. Researchers did not conduct direct interviews. The data were taken from questionnaires which were sometimes inconsistent in providing answers.

Suggestions in this research are: The Pidie District Government needs to conduct several trainings to improve apparatus competence and disseminate regulations related to gampong budgets or more effective village budget management. The gampong apparatus needs to improve a better understanding of the competence and understanding of the regulations required so that the management of the village budget is better. For researchers, it is necessary to add other variables that affect the effectiveness of village budget management such as internal supervision, organizational commitment, and others. Further researchers are also advised not only to use a questionnaire but also to use the interview method so that the data obtained is biased more accurately. 


\section{References}

AcehTribunnews (2019). The Pidie Gampong Empowerment Service (PMG) Records Two Gampong Threatened to Fail to Disburse Gampong Funds in 2019. Article online viahttps://aceh.tribunnews.com/2019/12/02/dana-desa-rp-17-m-di-dua-gampong-dipidie-akan-gagal-dicairkan-ini-the problem. Accessed on 15/01/2020.

Elfin, AB Wawo \& Husin. (2019). The Influence of Village Apparatus Competence, Commitment to Duties and Regulations on Village Financial Management in Bombana Regency. Journal of Economic Development Progress (JPEP), 4 (2), 6886.

Ferina, IS, Burhanuddin, \& Lubis, H. (2014). Review of Village Government Readiness in Implementing Minister of Home Affairs Regulation Number 1137

Finance Des. Sriwijaya Journal of Management and Business, 14 (3), 321-336.

Halim, A. \& Abdullah, S. (2006). Studies on Capital Expenditures in Regional Government Budgets in Relation to Maintenance Expenditures and Revenue Sources. Journal of Government Accounting. 2 (2), 17 -32.

Herwan. (2019). The Effect of Internal Control, Village Government Apparatus Competence and Information Technology Utilization on the Effectiveness of Village Financial Management. Thesis. Master Program in Accounting, University of Lampung.

Indrajaya, JA (2017). Effect of Village Apparatus Competence and Implementation of Law No. 6 of 2014 on Village Fund Financial Management. Articles online viahttp://digilib.unila.ac. Accessed on 22/01/2020.

Irvan, N., AR Mus, M. Su'un, M. Sufri. (2017). Effect of Human Resource Competencies, Information Technology and Internal Control Systems on Good Governance and Local Government Financial Management Performance. IRA-International Journal of Management \& Social Sciences, 8 (1), 31-45.

Lane, JE (2013). The Principal-Agent Approach to Politics: Policy Implementation and Public Policy-Making. Open Journal of Political Science, 3 (2), 85-89.

Mahmudi. (2005). Public Sector Performance Management. Yogyakarta: UPP AMP YKPN.

Murthy, DNP \& Jack, N. (2017). Game Theoretic Modeling of Service Agent Warranty Fraud. Journal of the Operational Research Society. 68 (11), 1399-1408.

Nurillah, AS (2014). The Influence of Human Resource Competence, Implementation of Regional Financial Accounting Systems (SAKD), Utilization of Information Technology, and Internal Control Systems on the Quality of Regional Government Financial Reports. Online articles via Eprints. Undip.Ac.Id. Accessed on 15/01/2020.

Regulation of the Minister of Home Affairs (Pemendagri) Number 20 of 2018 concerning Guidelines for Village Financial Management.

Minister of Home Affairs Regulation No. 113 of 2014 concerning Village Financial Management.

Government Regulation No. 56 of 2005 concerning Regional Financial Information Systems.

Presidential Regulation Number 192 of 2014 concerning the Financial and Development Supervisory Agency (BPKP)

Pidie Regency Qanun Number 8 Year 2011 concerning Gampong Governance.

Ridwan. MA (2019). Analysis of the Role of Village Financial System Applications (Siskeudes) in Improving the Quality of Village Financial Accountability in View of 
an Islamic Economic Perspective. Essay. Faculty of Economics and Islamic Business, Raden Intan State Islamic University, Lampung.

Sapartiningsih, D., Suharno, D. Kristianto. (2018). Analysis of the Influence of Human Resource Competence, Utilization of Information Technology, Participation in Budgeting and Supervision on Accountability of Village Fund Management. Journal of Accounting and Information Technology Systems, 14 (1), 100-14.

Spanint.kemenkeu.go.id, (2020).https://spanint.kemenkeu.go.id/spanint/latest/ app / \# dak / danaDesa4 / serapDD /Pidie. Accessed on 15/06/2020.

Sinarpidie (2019). 8 Gampong in Pidie Has Not Delivered LPJ 2018, Village Fund 2019 Is Threatened That It Cannot Be Liquid. Articles online viahttps://sinarpidie.co/ news / 8-gampong-di-pidie-not-yet-submitted-lpj-2018-village-funds-2019-threatened-can'tget-liquid / index.html. Accessed on 15/01/2020.

Sugiyono. (2013). Qualitative and Quantitative Research Methods R \& D. Bandung: Alfabeta.

Tambunan, MIP (2019). Application of Village Financial System Application in Improving Village Apparatus Performance (Case Study of Bogorejo Village, Gedong Tataan Sub-district, Pesawaran District). Articles online viahttp://digilib.unila.ac.id/ 59242 /. Accessed on 15/01/2020.

Law Number 6 of 2014 concerning Villages.

Wardani, DK \& Andriyani, I. (2017). The Effect of Human Resources Quality, Utilization of Information Technology, and Internal Control Systems on the Reliability of Village Government Financial Reporting in Klaten Regency. Journal of Accounting University of Undergraduate Wiyata Tamansiswa, 5 (2), 88-98.

Winidyaningrum, C., \& Rahmawati. (2010). Influence of Human Resources and Utilization of Information Technology on Reliability and Timeliness of Regional Government Financial Reporting with Variables Intervening Internal Accounting Control. National Symposium Accounting, XIII, Purwokerto. 